\title{
Novel Aminated Cellulose Acetate Membranes for Direct Methanol Fuel Cells (DMFCs)
}

\author{
M. S. Mohy Eldin ${ }^{1.2, *}$, A. M. Omer ${ }^{2 *}$, T. M. Tamer ${ }^{2}$, M. H. Abd Elmageed ${ }^{3}$, M. E. Youssef ${ }^{4}$, \\ R. E. Khalifa ${ }^{2}$ \\ ${ }^{1}$ Chemistry Department, Faculty of Science, University of Jeddah, Asfan, P. O. Box: 80203, Jeddah \\ 21589, Saudi Arabia \\ ${ }^{2}$ Polymer Materials Research Department, Advanced Technology and New Materials Research \\ Institute, SRTA-City, New Borg El-Arab City 21934, Alexandria, Egypt \\ ${ }^{3}$ Chemical Engineering Department, Faculty of Engineering, Alexandria University, Alexandria, \\ Egypt. \\ ${ }^{4}$ Computer-Based Engineering Applications Department, Informatics Research Institute, MUCSAT, \\ New Borg El-Arab City 21934, Alexandria, Egypt \\ *E-mail: m.mohyeldin@mucsat.sci.eg, Ahmedomer_81@yahoo.com
}

doi: $10.20964 / 2017.05 .67$

Received: 8 July 2016 / Accepted: 19 January 2017 / Published: 12 April 2017

Currently, enhancing the mechanical properties and decreasing methanol permeability is the major challenge for the polyelectrolyte membranes for the direct methanol fuel cells (DMFCs). In this study, novel aminated proton exchange membrane based on cellulose acetate (CA) for DMFC were prepared via activation process using epichlorohydrin $(\mathrm{ECH})$ afterward amination reaction using ethylene diamine (EDA). The structure of the aminated cellulose acetate membranes (AMCA) were investigated by a Fourier transform infrared spectroscopy, Scanning electron microscopy, Thermogravimetric analysis. The adsorption of the AMCA membrane of water and methanol solution was also characterized. Additionally, the AMCA membranes were investigated as a function of a molar ratio of EDA concerning ion exchange capacity (IEC), dimensional stability, thickness change, thermal oxidation stability, and methanol permeability in detail. Results revealed that the modified CA membranes have excellent dimensional stability, admirable physicomechanical properties $(32.13 \mathrm{~N})$ and low methanol permeability $(4.54 * 10-17 \mathrm{~cm} 2 / \mathrm{S})$ compared to $1.14 * 10-9 \mathrm{~cm} 2 / \mathrm{S}$ for commercial Nafion ${ }^{\circledR} 117$ membranes. Furthermore, the membrane performance with various contents of EDA showed a vast improvement compared to Nafion ${ }^{\circledR} 117$. In conclusion, the obtained series of AMCA membranes offering the possibilities to reduce the DMFC membrane cost considerably while keeping high performance. These results suggested that these membranes are quite attractive candidates as an innovative polymeric electrolyte material for DMFCs applications. 
Keywords: Proton exchange membranes; Cellulose acetate; Methanol permeability; Ethylene diamine; Direct methanol fuel cell.

\section{$\underline{\text { FULL TEXT }}$}

(C) 2017 The Authors. Published by ESG (www.electrochemsci.org). This article is an open access article distributed under the terms and conditions of the Creative Commons Attribution license (http://creativecommons.org/licenses/by/4.0/). 